\title{
AGE AND GROWTH OF THE STRIPED SEABREAM, LITHOGNATHUS MORMYRUS (ACTINOPTERYGII: PERCIFORMES: SPARIDAE), IN THE CENTRAL COAST OF ALGERIA, MEDITERRANEAN SEA
}

\author{
Samira BOUFERSAOUI ${ }^{*}$, Abderrahmane KASSAR ${ }^{1}$, Zakia MOKRANE$^{2}$, \\ Romain ELLEBOODE ${ }^{3}$, and Kélig MAHÉ ${ }^{3}$ \\ ${ }^{1}$ Ecole Nationale Supérieure des Sciences de la Mer et de l'Aménagement du Littoral, Algiers, Algeria \\ ${ }^{2}$ Centre National de Recherche et de Développement de la Pêche et de l'Aquaculture, Bou Ismaïl, Tipaza, Algeria \\ ${ }^{3}$ Institut Français de Recherche pour l'exploitation de la mer (IFREMER), Laboratoire Ressources Halieutiques, \\ Pôle de Sclérochronologie, Boulogne-sur-Mer, France
}
Boufersaoui S., Kassar A., MokraneZ., Elleboode R., Mahé K. 2018. Age and growth of the striped seabream, Lithognathus mormyrus (Actinopterygii: Perciformes: Sparidae), in the central coast of Algeria, Mediterranean Sea. Acta Ichthyol. Piscat. 48 (4): 319-328.

Background. Striped seabream, Lithognathus mormyrus (Linnaeus, 1758), is a bony fish, which has a high economic value on the Algerian coast. Because of the increasing fishing pressure, however, a close monitoring is recommended. The information about the biology of this species, occurring in the south-western Mediterranean Sea and especially in the north African coast, is very limited. The presently reported study provides new estimated data on age and growth parameters of striped seabream in Algeria.

Materials and methods. A total of 449 specimens of L. mormyrus were sampled for 2 years (January 2013 to December 2014) from the commercial fishery in the central part of the Algerian coast. The samples were collected monthly. The fish ranged in size from $11.5 \mathrm{~cm}$ to $34.5 \mathrm{~cm}$ and weighed between $21.6 \mathrm{~g}$ and $540.3 \mathrm{~g}$. We analysed the sagittal otolith morphology and morphometry to determine a relation with the fish ontogeny. Fish age was determined from the sagittal otoliths to identify growth structures based on digitally processed otolith images aided by the TNPC software.

Results. No significant difference between the two otoliths (left and right) was detected (ANCOVA, $P>0.05$ ). The correlation between each biometric parameter of the otolith (length and width) and fish length (TL) was significant (ANCOVA, $P<0.05$ ). The evolution of marginal increment analysis (MI) showed that the annual periodicity of the growth ring was between July and December. The growth parameters of the von Bertalanffy model were estimated for each sex separately. In females they assumed the following values: $\mathrm{TL}_{\infty}=35.44 \mathrm{~cm}$, $K=0.27 \mathrm{yr}^{-1}$, and $t_{0}=-1.25 \mathrm{yr}$, while in males $-\mathrm{TL}_{\infty}=26.94 \mathrm{~cm}$ and $K=0.6 \mathrm{yr}^{-1}, t_{0}=-0.45 \mathrm{yr}$. The asymptotic length was higher in females than in males. Males were represented only by small specimens and less than or equal to four years of age.

Conclusion. The presently reported results are the first ones on the age and growth of L. mormyrus off the Algerian coast. They will hopefully improve future stock management to get a sustainable fishery.

Keywords: Lithognathus mormyrus, otolith, age, growth, Algerian coast, Mediterranean Sea

\section{INTRODUCTION}

Seabreams (Sparidae) are found in coastal waters worldwide and sustain important recreational and commercial fisheries (Fischer et al. 1987). This family belongs to the perch-like fishes (Perciformes) comprising more than 100 species. In the Mediterranean Sea, there are 24 seabream species, representing 11 genera (Nelson 2006). One of the representatives of the Sparidae in
Algeria is the striped seabream, Lithognathus mormyrus (Linnaeus, 1758). This species is widespread and common throughout much of its range in the Mediterranean Sea. It is present in the Atlantic Ocean from the Bay of Biscay (France) to the Cape of Good Hope (South Africa), in the Red Sea, and the south-western Indian Ocean (Kallianiotis et al. 2005). This wide geographical distribution indicates a good adaptability to different environmental conditions, 
hence its importance in farming. Studies of wild fish 2012 and 2014 (database of the Algerian Ministry of populations are of interest in terms of assessment and Fisheries). management of fish stocks (Bailey 1997, Turan 1999).

Lithognathus mormyrus is usually captured between depths of 10 and $30 \mathrm{~m}$ (Jardas 1996). The species is a protandrous hermaphrodite fish (Besseau and Faliex 1990). In the Mediterranean Sea, the sex-inversion occurs between 21 and $30 \mathrm{~cm}$ (4-9 yr). Males and females reach sexual maturity at $16.2 \mathrm{~cm}(2.5 \mathrm{yr})$ and $19.04 \mathrm{~cm}(3.6$ yr), respectively (Kallianiotis et al. 2005). The spawning period is from May to September, while the gamete emission peaks between June and August (Kallianiotis et al. 2005).

Suau (1970) has studied some aspects of reproduction, age, and growth of L. mormyrus in the Mediterranean Sea and in eastern Spanish coastal waters. Papaconstantinou et al. (1988) published data about the geographical distribution of striped seabream in Greek seas and Koutrakis and Tsikliras (2003) reported a length-weight relation for this fish. Studies on the feeding behaviour of L. mormyrus in the Mediterranean Sea were carried out by Suau (1970), Badalamenti et al. (1993), Bradaï et al. (1998), Chessa et al. (2005), Harchouche et al. (2005), Kallianiotis et al. (2005), and Ben Hadj Hamida et al. (2015). In the southern Mediterranean, data on age, growth, and reproduction in the Gulf of Gabes (southeastern Tunisia) have recently been reported by Ben Abdallah-Ben Hadj Hamida et al. (2016). However, there are no published results on age and growth of L. mormyrus in Algeria.

In Algerian coasts, total landings of striped seabream declined in recent years and the commercial production in terms of weight reached $8.9 \mathrm{t}$ in 2014 (data acquired from an unpublished database of the Algerian Ministry of Fisheries). In the Algerian fisheries, L. mormyrus is caught by a multi-gear fishing, mainly with trammel nets and secondary with bottom trawling. These two kinds of fishing gears accounted respectively for $80 \%$ and $20 \%$ of the total catch of striped seabream in the region between

Despite the FAO catch statistics, which indicate a stable population over the last ten years in the Eastern Mediterranean Sea, there are some signs indicating that the population of L. mormyrus has been affected by overfishing and may also indicate future decline, thus, the species has a 'least concern' status in the IUCN (The International Union for Conservation of Nature) Red List of Threatened Species (Russel et al. 2014).

The aim of the presently reported study was to

- Provide new information on the otolith morphology (weight, length, width) and body size (total length, TL) relations.

- Determine if the otolith morphology is correlated with the fish length.

- Estimate the fish age to evaluate the growth of this species in the Algerian coast, with the indirect growth validation from the marginal increment analysis.

Ageing and growth parameter estimation are also fundamental prerequisites for studies in population dynamics and for stock assessment.

\section{MATERIALS AND METHODS}

Sampling. A total of 449 specimens of Lithognathus mormyrus was collected from commercial fleet fishing in the central region of Algeria (south-western Mediterranean Sea) within 2013-2015 (Fig. 1). During these two years, samples were collected monthly. The majority of the specimens were caught by trammel nets, while the remaining ones were captured by bottom trawling. For each fish, the total length (TL) and the total weight (TW) were determined to the nearest $0.1 \mathrm{~mm}$ and $0.01 \mathrm{~g}$, respectively.

Analysis of whole otoliths. The sagittal otoliths were extracted, cleaned, and stored dry for subsequent examination. Individual otolith weight (OW) was determined, to the nearest $0.01 \mathrm{mg}$, using an electronic balance. Otoliths immersed in water were scanned with

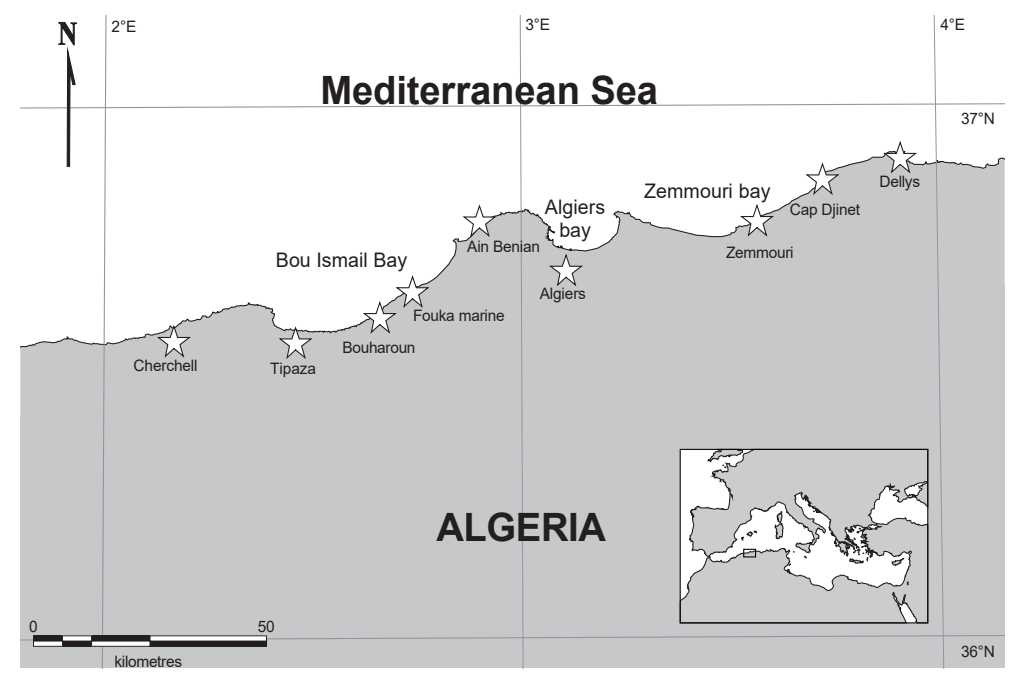

Fig. 1. Central coast of Algeria in the Mediterranean Sea and sampling sites (stars) of striped seabream, Lithognathus mormyrus 
Epson Pro V750 and the images were saved on a computer disc. Otoliths were scanned in reflected light by placing the concave side of the otolith against the glass surface. The scanning process was performed in the dark, with an open scanner cover to get a black background. Each otolith was then analysed using the TNPC software (on digital processing of calcified structures, developed by IFREMER in collaboration with the company VSG, Visualization Sciences Group formerly Noesis). To limit interpretation errors, two different readers examined each otolith. Otolith length (OL) and width (OWi) were measured to the nearest $0.001 \mathrm{~mm}$. The otolith length was defined as the longest axis between the anterior and the posterior otolith edges and width as the distance from dorsal to ventral edges taken perpendicular to the length through the otolith focus. Analysis of covariance (ANCOVA) was used to evaluate the differences between the fitted total length/otolith parameters (Ow after log transformation, OL, and OWi) relations according to the left and right side of the inner ear.

Age validation. The age ( $\pm 1 \mathrm{yr})$ was estimated using reflected light and a dark background considering 1 January as the nominal birth date. The age was estimated by counting the number of growth increment from the nucleus to the edge. One-year growth increment was represented by one opaque and one translucent ring. The age of each fish was assigned to a year class, taking into account the date of capture, the growth increment formation period, and nature of edge bands (MoralesNin 1987).

The annuli were measured along the ventroanterior direction (Fig. 2). The growth rate was assessed using attempting to determine when growth increments were formed by monthly measurement of the marginal increment (MI), according to the formula

$$
\mathrm{MI}=\left(R_{o}-R_{n}\right) \cdot\left(R_{n}-R_{n-1}\right)^{-1}
$$

where $R_{\mathrm{o}}$ is the otolith radius from the nucleus to the edge, $R_{o}-R_{n}$ is the distance between the edge and the last growth ring, and $R_{n}-R_{n-1}$ is the distance between the edge and the second to the last ring (Fig. 2). The minimal value of marginal increment was used to indicate the month of growth increment formation.

Growth analysis. Growth analysis was measured by the von Bertalanffy model (von Bertalanffy 1938) according to the equation

$$
\mathrm{TL}_{\mathrm{t}}=\mathrm{TL}_{\infty} \cdot\left(1-\mathrm{e}^{-\mathrm{K} \cdot\left(\mathrm{t}-\mathrm{t}_{0}\right)}\right)
$$

where $\mathrm{TL}_{t}$ is the total length at age $t, \mathrm{TL}_{\infty}$ is the total asymptotic length, $K$ is the growth coefficient, and $t_{0}$ is the theoretical age at which length equals zero (fitted parameters). Models per sex and for both were generated using the FSA package* in the open source R program.

To research potential differences in growth parameters between males and females, maximum likelihood ratio tests (Kimura 1980) were calculated using the fishmethods

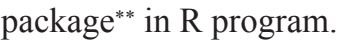

The phi-prime test $\left(\phi^{\prime}\right)$ (Munro and Pauly 1983) was used to compare the values of the growth parameters given in the present paper with those reported by other authors for the same species

$$
\phi^{\prime}=\log _{10} \mathrm{k}+2 \log _{10} \mathrm{TL}_{\infty}
$$

Length-weight relations (LWRs) for each sex and combined sexes were calculated with

$$
\mathrm{TW}=\mathrm{a} \cdot \mathrm{TL}^{\mathrm{b}}
$$

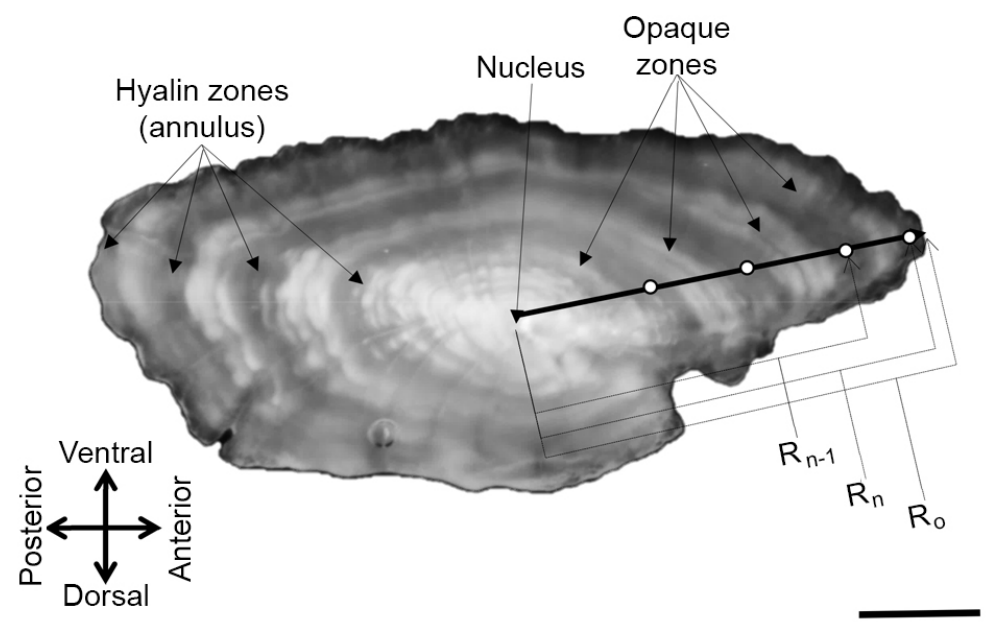

Fig. 2. Otolith interpretation from a four-year-old specimen of striped seabream, Lithognathus mormyrus from Algeria, showing the annual rings; $R_{\mathrm{o}}=$ otolith radius, $R_{\mathrm{n}}=$ distance between the nucleus and the last growth ring, and $R_{\mathrm{n}-1}=$ distance between the nucleus and the ring before the last one; scale bar $=2 \mathrm{~mm}$

\footnotetext{
" http://CRAN.R-project.org/package=FSA

" http://CRAN.R-project.org/package=fishmethods.
} 
where TW is the fish total weight $[\mathrm{g}]$ and TL is the total length [cm]. LWRs are originally used to provide information on the condition of fish and may help determine whether somatic growth (Ricker 1973, Spiegel et al. 1991). Values of the exponent $b$ provide information on fish growth. When $b=3$, the increase in weight is considered isometric. When the value of $b$ is other than 3 , the weight increase is allometric (positive allometry if $b>3$, negative allometry if $b<3$ ). The null hypothesis of isometric growth $\left(H_{0}: b=3\right)$ was tested by Student $t$-test (ts), using the formula

$$
\text { ts }=(b-3) \cdot \mathrm{S} b^{-1}
$$

where $\mathrm{S} b$ is the standard error of the slope for $\alpha=0.05$ for testing significant differences among slopes $(b)$ between two regressions (Morey et al. 2003). The determination coefficient $\left(r^{2}\right)$ is used to calculate the association degree between length-weight variables were calculated.

\section{RESULTS}

Among a total of 449 sampled specimens of Lithognathus mormyrus, 132 were males, 204 females, and 36 bisexual specimens (individuals with ovotestis, i.e., testis and ovarian parts in the same gonad). The sex of the residual 77 specimens could not be macroscopically determined as they had a very thin and translucent immature gonad, or the fish was very damaged due to its deteriorating state. These unknown fish were found within the size range of $11.3-23.0 \mathrm{~cm}$. The length of males ranged between 11.8 and $33.8 \mathrm{~cm}$, females between 12.8 and $33.5 \mathrm{~cm}$, and bisexual individuals from 14.7 to $34.5 \mathrm{~cm}$ (Fig. 3).

The majority of males were small-size individuals (TL range: 13-27 cm, TL mean: $22.7 \mathrm{~cm}$ ). The majority of females were represented by length classes larger than $19 \mathrm{~cm}$. Bisexual specimens made up $8.02 \%$ of the specimens examined and were observed in smaller and intermediate sizes $(11-27 \mathrm{~cm})$, although the proportion of males decreased as the length increased.

The length-weight regressions indicated an isometric nature of growth in males, females, and the whole sample (Table 1).
Table 1

Length-weight relation parameters for striped seabream, Lithognathus mormyrus from Algeria

\begin{tabular}{lccccccc}
\hline \multicolumn{1}{c}{ Sex } & $a$ & $b$ & $n$ & $\mathrm{SE}(b)$ & $r^{2}$ & $P$ & Relation \\
\hline Males & 0.012 & 3.029 & 132 & 0.01 & 0.979 & 0.941 & Isometry \\
Females & 0.012 & 3.038 & 204 & 0.015 & 0.983 & 0.901 & Isometry \\
All & 0.010 & 3.094 & 449 & 0.006 & 0.979 & 0.837 & Isometry \\
\hline
\end{tabular}

$a=$ intercept, $b=$ slope, $n=$ sample size, $\mathrm{SE}(b)=$ standard error of slope $b, r^{2}=$ determination coefficient, $P=$ probability of the $t$-test $\left(H_{0}: b=3\right)$.

The otolith of L. mormyrus was oval, slightly elongated in the cubiceps area. Rostrum was protruded and rounded. Antirostrum was flat or very slightly rounded. For average length fish, the general shape was slightly elongated at the rostrum, the borders were toothed. For large fish, it was observed that the otoliths were very extended in the rostrum, the peaks were well defined with dissimilar lobes.

The symmetry between left and right otoliths was assessed, and there was no significant difference (ANCOVA, $P=0.43$ ). Consequently, we arbitrarily used the right otolith for all measurements done in the subsequent analysis. Table 1 shows ranges of otolith descriptors. Regression between fish total length and each morphological descriptor of the otolith (length OL, weight OW, and width OWi), according to the studied sex, were given in Table 2 . There was a significant relation between fish length and all otolith descriptors (ANCOVA, $P<0.05$ ). The results indicated no significant difference between male and female specimens (ANCOVA, $P>0.05$ ).

The annual periodicity of growth increments was confirmed by the marginal increment analysis (Fig. 4). Rapid-growth periods (opaque rings) were formed mainly in summer-autumn and slow-growth periods (hyaline rings) were more frequent in winter-spring. The opaque area started to form in July, corresponding to a sharp decrease in the marginal increment. During the rest of the year, there was a progressive increase in the marginal increment. The observation and interpretation of the otoliths had a percentage of agreement of $95 \%$ between the two different readers. Striped seabreams sampled in this study were aged from one to seven years old (Table 3 ).

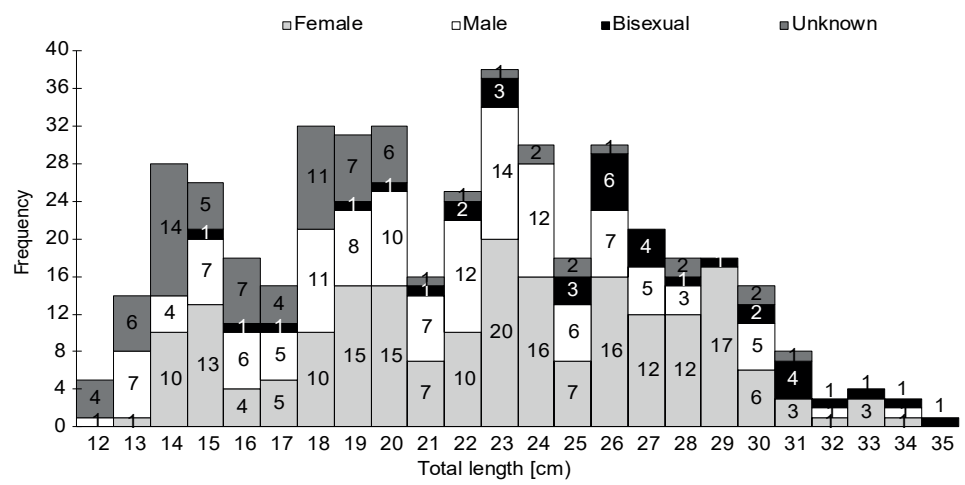

Fig. 3. Length-frequency distributions for males, females, and hermaphrodites of striped seabream, Lithognathus mormyrus from Algeria by size intervals in the study area; number of specimens is indicated inside the columns 
Table 2

Ranges of values and relations between otolith morphometric parameters and the length of striped seabream, Lithognathus mormyrus from Algeria

\begin{tabular}{lccc}
\hline \multicolumn{1}{c}{ Parameter } & Female & Males & All \\
\hline Sample size $(n)$ & 182 & 123 & 415 \\
TL range $[\mathrm{cm}]$ & $12.8-33.5$ & $13.0-33.8$ & $11.5-34.5$ \\
TL mean $\pm \mathrm{SE}[\mathrm{cm}]$ & $22.89 \pm 0.38$ & $21.17 \pm 0.410$ & $21.65 \pm 0.26$ \\
OL range $[\mathrm{mm}]$ & $3.79-10.42$ & $3.68-9.00$ & $3.68-10.42$ \\
OL mean $\pm \mathrm{SE}[\mathrm{mm}]$ & $7.26 \pm 0.09$ & $6.73 \pm 0.10$ & $6.94 \pm 0.06$ \\
OWi range $[\mathrm{mm}]$ & $2.02-5.10$ & $2.10-4.34$ & $2.10-5.10$ \\
OWi mean $\pm \mathrm{SE}[\mathrm{mm}]$ & $3.66 \pm 0.04$ & $3.43 \pm 0.04$ & $3.52 \pm 0.50$ \\
ROW range $[\mathrm{mm}]$ & $0.011-0.077$ & $0.011-0.054$ & $0.005-0.083$ \\
ROW mean $\pm \mathrm{SE}[\mathrm{mm}]$ & $0.0316 \pm 0.00093$ & $0.0275 \pm 0.00085$ & $0.0285 \pm 0.0245$ \\
LOW range $[\mathrm{mm}]$ & $0.011-0.077$ & $0.012-0.052$ & $0.005-0.085$ \\
LOW mean $\pm \mathrm{SE}[\mathrm{mm}]$ & $0.0312 \pm 0.00094$ & $0.0276 \pm 0.0089$ & $0.0284 \pm 0.0006$ \\
OL vs. TL & $\mathrm{TL}=36.46 \mathrm{OL}-3.59$ & $\mathrm{TL}=37.38 \mathrm{OL}-3.97$ & $\mathrm{TL}=37.82 \mathrm{OL}-4.59$ \\
& $r^{2}=0.85, P<0.05$ & $r^{2}=0.80, P<0.05$ & $r^{2}=0.87, P<0.05$ \\
OWi vs. TL & $\mathrm{TL}=83.41 \mathrm{OWi}-7.62$ & $\mathrm{TL}=77.78 \mathrm{OWi}-5.51$ & $\mathrm{TL}=89.24 \mathrm{OWi}-9.75$ \\
& $r^{2}=0.97, P<0.05$ & $r^{2}=0.60, P<0.05$ & $r^{2}=0.70, P<0.05$ \\
OW vs. TL & $\mathrm{TL}=128.42 \mathrm{OW} 0.50$ & $\mathrm{TL}=144.31 \mathrm{OW} 0.53$ & $\mathrm{TL}=137.36 \mathrm{OW}$ \\
& $r^{2}=0.82, P<0.05$ & $r^{2}=0.83, P<0.05$ & $r^{2}=0.85, P<0.05$ \\
\hline
\end{tabular}

$\mathrm{TL}=$ total length, $\mathrm{OL}=$ otolith length, $\mathrm{OWi}=$ otolith width, $\mathrm{ROW}=$ right otolith weight, $\mathrm{LOW}=$ left otolith weight, $r^{2}=$ coefficient of determination, $P=$ probability or significance level (ANCOVA test); $\mathrm{SE}=$ standard error of the mean; all regressions were significant (ANCOVA, $P<0.05$ )

Table 3

Mean measured total length at estimated age class for striped seabream, Lithognathus mormyrus from Algeria

\begin{tabular}{|c|c|c|c|c|c|c|c|c|c|}
\hline \multirow{3}{*}{$\begin{array}{l}\tilde{y} \\
\tilde{\Xi} \\
0 \\
0 \\
0 \\
\mathbb{8}\end{array}$} & \multicolumn{9}{|c|}{ Total length $[\mathrm{cm}]$} \\
\hline & \multicolumn{3}{|c|}{ All } & \multicolumn{3}{|c|}{ Females } & \multicolumn{3}{|c|}{ Males } \\
\hline & $n$ & Mean \pm SD & Range & $n$ & Mean \pm SD & Range & $n$ & Mean \pm SD & Range \\
\hline I & 114 & $15.61 \pm 2.36$ & $11.50-26.00$ & 35 & $15.93 \pm 2.10$ & $12.80-20.30$ & 27 & $15.64 \pm 2.24$ & $11.80-20.40$ \\
\hline II & 119 & $20.94 \pm 3.57$ & $13.00-27.70$ & 42 & $20.95 \pm 3.34$ & $13.90-27.00$ & 52 & $20.66 \pm 3.69$ & $13.00-27.50$ \\
\hline III & 127 & $23.64 \pm 3.66$ & $15.30-32.90$ & 76 & $23.68 \pm 3.65$ & $15.30-32.90$ & 36 & $23.65 \pm 3.62$ & $17.70-31.50$ \\
\hline IV & 68 & $26.66 \pm 3.31$ & $20.00-33.80$ & 38 & $27.19 \pm 2.88$ & $20.00-33.50$ & 17 & $24.94 \pm 3.83$ & $20.10-33.80$ \\
\hline $\mathrm{V}$ & 18 & $29.16 \pm 3.31$ & $23.10-33.70$ & 12 & $28.69 \pm 3.19$ & $23.10-33.30$ & 0 & - & - \\
\hline VI & 2 & $32.85 \pm 2.33$ & $31.20-34.50$ & 0 & - & - & 0 & - & - \\
\hline VII & 1 & $29.80 \pm 0.00$ & $29.80-29.80$ & 1 & 29.80 & 29.80 & 0 & - & - \\
\hline
\end{tabular}

$n=$ sample size, $\mathrm{SD}=$ standard deviation.

The von Bertalanffy growth parameters and curves are shown respectively in Table 4 and in Fig. 5. The estimated growth parameters of the model in this study were: $\mathrm{TL}_{\infty}=26.94 \mathrm{~cm}, K=0.6 \mathrm{yr}^{-1}, t_{0}=-0.45 \mathrm{yr}$ for males; and $\mathrm{TL}_{\infty}=35.44 \mathrm{~cm}, K=0.27 \mathrm{yr}^{-1}, t_{0}=-1.25 \mathrm{yr}$ for females, and $L_{\infty}=34.85 \mathrm{~cm}, K=0.28 \mathrm{yr}^{-1}, t_{0}=-1.12 \mathrm{yr}$ for all individuals. The growth pattern differed between sexes in this study, with significant differences between males and females. The obtained value of the growth performance index $\left(\phi^{\prime}\right)$ was 2.64 and $2.53 \mathrm{yr}^{-1}$ for males and females, respectively. These values and growth curves indicated that male grew faster and reached a smaller maximum size than females; females grew to a superior asymptotic total length $\left(\mathrm{TL}_{\infty}\right)$ than males. A likelihood ratio test confirmed a significant difference between the von Bertalanffy growth functions for males and females.

\section{DISCUSSION}

Fischer et al. (1987) reported that Lithognathus mormyrus usually grows up to $30 \mathrm{~cm}$ but it can reach length (TL) of $55 \mathrm{~cm}$. The majority of captured individuals represent the length range of $15-30 \mathrm{~cm}$.

The maximum length and weight reported in this study $(\mathrm{TL}=34.5 \mathrm{~cm}$ for $\mathrm{TW}=540.26 \mathrm{~g})$ are the biggest reported values in the southern Mediterranean Sea. Türkmen and Akyurt (2003), Emre et al. (2010), and Ben AbdallahBen Hadj Hamida et al. (2016), in their studies in the Mediterranean Sea, reported that the larger individuals were $27.7,27.4$, and $24.1 \mathrm{~cm}$ in total length, respectively. Kraljević et al. (1996) observed that individuals of L. mormyrus from the northern Adriatic Sea reached a length of $38 \mathrm{~cm}$. A new maximum length in the Black Sea was recently reported by Aydin (2018). The biggest 
individual observed by the above-mentioned author was $30 \mathrm{~cm}$ in total length. In the Atlantic Ocean, Dorel (1986) observed a $52.5 \mathrm{~cm}$ (TL) specimen collected in the Bay of Biscay. Later in the same ocean, Pajuelo et al. (2002), reported individuals from the Canary Islands, attaining $30 \mathrm{~cm}$ in length (TL). In general, it can be argued that the growth of striped seabream in the Atlantic Ocean is faster than that in the Mediterranean Sea.

During the presently reported study, isometric growth was determined between weight and length of the whole sample, and for females and males separately. For the same

Table 4

Von Bertalanffy growth parameters in length for males, females, and all specimens of striped seabream, Lithognathus mormyrus from Algeria

\begin{tabular}{cccccc}
\hline Sex & $\mathrm{TL}_{\infty}[\mathrm{cm}]$ & $K\left[\mathrm{yr}^{-1}\right]$ & $t_{0}[\mathrm{yr}]$ & $n$ & $\phi^{\prime}\left[\mathrm{cm} \cdot \mathrm{yr}^{-1}\right]$ \\
\hline Males & 26.94 & 0.60 & -0.45 & 132 & 2.64 \\
Females & 35.44 & 0.27 & -1.25 & 204 & 2.53 \\
All & 34.85 & 0.28 & -1.12 & 449 & 2.54 \\
\hline
\end{tabular}

$\mathrm{TL}_{\infty}=$ asymptotic length, $K=$ growth coefficient, $t_{0}=$ theoretical age at zero length, $n=$ sample number, $\phi^{\prime}=$ growth performance index.

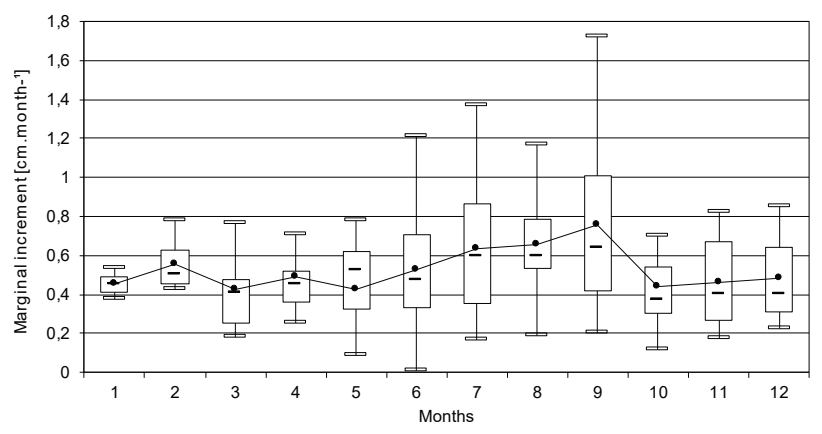

Fig. 4. Box plots of the mean marginal increment (cm per month; mean) indices of striped seabream, Lithognathus mormyrus from Algeria by month; boxes $=50 \%$ of the population between Q1 and Q3 around the median; whiskers show minimum and maximum values, excluding outliers species, similar type of growth was reported by Gonçalves et al. (1997) from the southern coast of Portugal ( $b=$ 2.81), by Santos et al. (2002) from the Algarve coast ( $b$ =3.02), by Türkmen and Akyurt (2003) from Iskenderun Bay, Turkey $(b=3.05)$, by Morey et al. (2003) from the Balearic Islands and the Iberian coast $(b=3.03)$, by Mariani (2006) from Caprolace, Latina Province, Italy ( $b$ =3.04), by Gökçe et al. (2007) from the northern Aegean Sea $(b=3.10)$, by Keskin and Gaygusuz (2010) from shallow waters of Erdek Bay, Sea of Marmara, Turkey $(b=3.095)$, and by Sümer (2012) from the Beymelek Lagoon, south-western Turkey $(b=3.001)$.

Even with an isometric type of growth the $t$-test in all these regions (statistically $b=3$ ), the differences in $b$ values can be due to a combination of one or more factors such as habitat, seasonal effect, degree of stomach fullness, gonad maturity and spawning period, health, preservation techniques, and differences in observed length ranges of the captured specimens (Erkoyuncu 1995, Li et al. 2013, Hossain et al. 2015, Tobes et al. 2016, Saleh and Soegianto 2017).

The results of LWRs reported in our study imply that the "cube law" (Froese 2006) can be applied to the species in the study area, $a$ and $b$ can be used as parameters in stocks assessment models for evaluation of the species status in the fisheries management. Results of the presently reported study can also serve as baseline data for species with no previous length-weight relations (LWRs) as well as for comparison with future studies of marine fishes especially in the south-western Mediterranean Sea.

There were no observed statistical differences between left and right sagittae otoliths for the striped seabream according to the relations between otolith descriptors (length, width, and weight) and the total length of fish. These differences are not usually observed for roundfish species (Panfili et al. 2002), although some exceptions were reported in whiting, Merlangius merlangus (Linnaeus, 1758) (see Mille et al. 2015), and annular seabream, Diplodus annularis (Linnaeus, 1758) (see Trojette et al. 2015). Such otolith shape differences between the right and left inner ears are common in flatfish species (Mille et al. 2015) as a consequence of body morphology asymmetry. Based on the current results, we recommend that studies

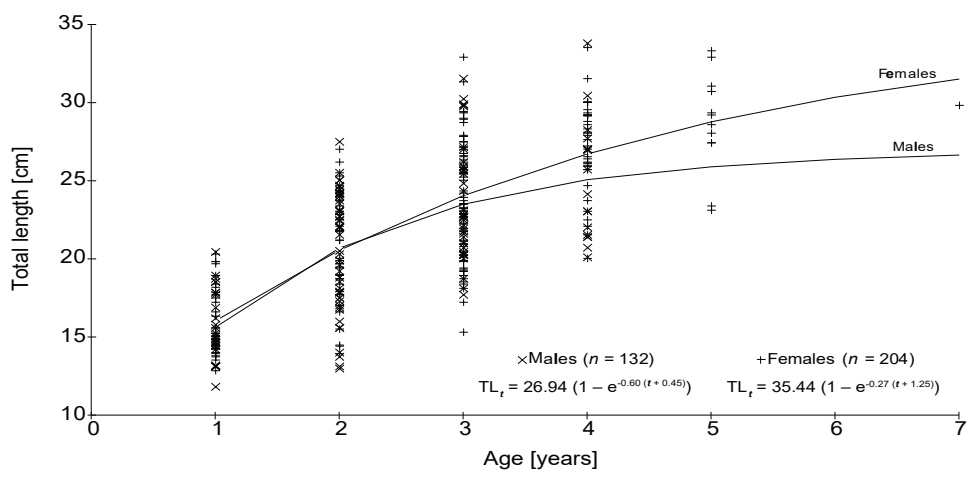

Fig. 5. The von Bertalanffy growth function (VBGF) for female and male striped seabream, Lithognathus mormyrus from Algeria (non-linear regression analysis); crosses and pluses are experimental values; lines are estimated curves; $\mathrm{TL}_{t}=$ total length at $t$ age, $t=$ age, $n=$ sample size 
of L. mormyrus stocks, based on otolith shape, should use only otoliths removed from the same side of the body.

After analysing the morphometric relations, we concluded that the otolith length, width, and the otolith weight are good indicators of the fish length. Total length and weight of fish can be estimated by otolith descriptors. There was a correlation between ontogenic and otolith growths. This result between otolith length and fish length suggested that otoliths could be used to estimate the age of the striped seabream. The regressions from this study can be useful for researchers examining the food habits of predators targeting L. mormyrus.

The marginal increment analysis demonstrated that otoliths of the striped seabream showed the common pattern known in teleost fishes with one opaque and one translucent zone formed each year in winter and summer, respectively. Morales-Nin and Ralston (1990) explained that seasonal growth cycles might be related to physiological changes produced by the influence of temperature, feeding regime, and the reproductive cycle. The opaque rings are formed during summer months when the sea temperature reaches the highest values, and the hyaline rings during winter months when the temperature is lower. The mean seawater temperature along the Algerian coast is $15^{\circ} \mathrm{C}$ in February and rises abruptly to $24^{\circ} \mathrm{C}$ in August-September. This increase in water temperature could be the main factor responsible for the opaque zone deposition. The highest percentages of otoliths with opaque rings at the margin were observed between May and September.

The oldest fish found in this study were at age of 7 , although these individuals were poorly represented in the landings. Comparing this result with other studies from the Mediterranean Sea, it is evident that the the reported age values were quite similar. These results were similar to those observed by Suau (1970) from the Spanish Mediterranean coast, by Türkmen and Akyurt (2003) from Iskenderun Bay, by Osman (2005) from the Mediterranean waters off Alexandria, and by Sümer et al. (2014) from the Beymelek Lagoon (south-western coast of Turkey). Recently Ben Abdallah-Ben Hadj Hamida et al. (2016) studying L. mormyrus from the same marine area (Gulf of Gabes, south-eastern Tunisia) reported fish individuals aged from 0 to 8 years old. In other regions, such as in eastern and northern Adriatic, Kraljević et al. (1995, 1996) found that striped seabream can attain an age of 8 and 12 years, respectively. Their results from 1995 are same as those obtained by Pajuelo et al. (2002) in the Canary Islands. In the southern coast of Portugal, the maximum observed age was 13 years (Monteiro et al. 2010). In the same region, Abecasis et al. (2008) announced that maximum observed ages were 13 years (40 cm TL) determined by otolith readings and 14 years (40 cm TL) by scale readings. The 14-year-old is the greatest age value found in the bibliography. In the Thracian Sea, the maximum observed age was 11 years (Kallianiotis et al. 2005). In the striped seabream studies of Lorenzo et al. (2002) and Vitale et al. (2011), the oldest fish observed in the waters of the Canary Islands (eastern central Atlantic) and in the Strait of Sicily were 10 years old. On the other hand, Emre et al. (2010) noted that the oldest fish observed in the Beymelek Lagoon represented the age of 4 years.

It is evident that variations in the age estimation are due to environmental and ecological factors present in different regions (Adriatic Sea, Canary Islands, Mediterranean Sea), but could also be a consequence of different methodology used for the age determination.

The growth model probably does not correctly describe the growth of juveniles of the striped seabream due to the lack of specimens in the 0 -age group in the sample. This could be explained by the fact that the juveniles of this species are not found in the coastal fishing areas during their early stages of life but live instead in adjacent coastal areas. As they are not recruited to the fishery, they are not taken with traditional commercial fishing gears operating in these areas.

This study suggested that the von Bertalanffy growth curves for L. mormyrus were significantly different between males and females. This sexual dimorphism observed in the growth patterns, seems to be related to the reproductive effort (Vieira et al. 2009). Growth and reproduction of individuals are determined by the interactive effects of two physiological processes, based on the partitioning of net production between growth and energy reserves (Houston and McNamara 1999). For the males, the absence of an energy switch between growth and reproduction is attributable to their lower energy demand for gonad development, thus most of their energy can be used for growth (Vieira et al. 2009).

The presently estimated growth parameters, however, are very similar to those reported by other authors for the southern Mediterranean (Suau 1970, Campillo 1992, Ben Abdallah-Ben Hadj Hamida et al. 2016). The only authors whose values diverged from this trend were Vitale et al. (2003). They obtained a higher value of TL $\mathrm{T}_{\infty}$ in the eastern Mediterranean, and it should be emphasized that their value approximated the highest one, which was estimated by Lorenzo et al. (2002) in Atlantic waters. The asymptotic length in the area investigated in the presently reported study $\left(\mathrm{TL}_{\infty}=34.85 \mathrm{~cm}\right)$ is smaller than that reported by Kraljević et al. (1995) for Mirna Bay in the northern Adriatic (Istria, Croatia) $\left(\mathrm{TL}_{\infty}=37.3 \mathrm{~cm}\right)$ and Kasùtela Bay in the central Adriatic $\left(\mathrm{TL}_{\infty}=36.2 \mathrm{~cm}\right)$. It was also smaller than that estimated by Kraljević et al. (1996), from the northern Adriatic $\left(\mathrm{TL}_{\infty}=40.1 \mathrm{~cm}\right)$. A comparison to the results of the same species in other regions has shown that striped seabream in the Beymelek Lagoon grew faster than other populations. It is known that the lagoons are highly productive systems (Labourg et al. 1985, Sümer et al. 2014). Newell (1982) pointed out that the reason for shallow, productive, and sheltered marine coastal systems, such as estuaries and coastal lagoons, are generally characterised by a strong spatial and temporal variability of physicochemical characteristics and productivity patterns. Moreover, lagoons often have high primary and secondary production rates and are valuable fishing areas. This is probably due to environmental conditions such as 
temperature, salinity, and food availability. Especially it has been proven that the temperature has a major influence on the growth of fish. The mean annual water temperature in the Beymelek Lagoon was $22.4^{\circ} \mathrm{C}$. This value is very high compared to those of seas and ocean areas (Kjerfve 1994). Also, differences in growth patterns between two regions can be attributed to differences in the size of the largest individual sampled in each area.

The results of $\phi^{\prime}$ in obtained the presently reported study were very similar to those found in other areas (Pajuelo et al. 2002, Lorenzo et al. 2002, Emre et al. 2010, Monteiro et al. 2010, Vitale et al. 2011). Some other studies (Türkmen and Akyurt 2003, Osman 2005, Ben Abdallah-Ben Hadj Hamida et al. 2016) showed that the growth performance index $\left(\phi^{\prime}\right)$ values differed only by 8.0 percentage points.

This observation indicates that the growth potential of striped seabream, Lithognathus mormyrus in different areas of the Mediterranean and elsewhere are quite comparable. The phi-prime test $\left(\phi^{\prime}\right)$ provides an indication of the estimation reliability since it has been suggested that $\phi^{\prime}$ values are similar for the same species and genera (Bellido et al. 2000).

The presently reported study provides the first information on the length distribution, length-weight relation, age, and growth of the striped seabream, Lithognathus mormyrus, in Algeria. These parameters, reported herewith, contribute to a better knowledge of the species, and are important for successful fisheries management. This study serves as baseline data on the south-western Mediterranean Sea and will be helpful in future fisheries research. For future biological studies on this species, the application of the relation between fish length and sagittal otolith measures could be studied for age estimation.

\section{ACKNOWLEDGEMENTS}

Authors are deeply grateful to Messrs Sabir Aissani and Soufiane Arrous who helped in fish collection.

\section{REFERENCES}

Abecasis D., Bentes L., Coelho R., Correia C., Lino P.G., Monteiro P., Gonçalves J.M.S., Ribeiro J., Erzini K. 2008. Ageing seabreams: A comparative study between scales and otoliths. Fishery Research 89 (1): 37-48. DOI: 10.1016/j.fishres.2007.08.013

Aydın M. 2018. The new maximum length of the striped sea bream (Lithognathus mormyrus L., 1758) in the Black Sea region. Aquatic Sciences and Engineering 33 (2): 50-52. DOI: 10.18864/ASE201808

Badalamenti F., D’Anna G., Fazio M., Gristina M., Lipari R. 1993. Relazioni trofiche tra quattro specie ittiche catturate su differenti substrati nel Golfo di Castellamare (Sicilia N/O). [Trophic relations between four fish species caught on different substrates in the Gulf of Castellamare (Sicily N/O).] Biologia Marina 1 (Suppl.): 145-150. [In Italian.]

Bailey K.M. 1997. Structural dynamics and ecology of flatfish populations. Journal of Sea Research 37 (3-4): 269-280. DOI: 10.1016/S1385-1101(97)00018-X
Bellido J.M., Pierce G.J., Romero J.L., Millán M. 2000. Use of frequency analysis methods to estimate growth of anchovy (Engraulis encrasicolus L. 1758) in the Gulf of Cádiz (SW Spain). Fisheries Research 48 (2): 107-115. DOI: 10.1016/S01657836(00)00183-1

Ben Abdallah-Ben Hadj Hamida O., Ben Hadj Hamida N., Chaouch H., Jarboui O., Missaoui H. 2016. Age, growth and reproduction of the striped sea bream Lithognathus mormyrus (Linnaeus, 1758) in the gulf of Gabes (southeastern Tunisia, central Mediterranean). Cahiers de Biologie Marine 57 (2): 113-123. DOI: 10.21411/CBM.A.894A1E28

Ben Hadj Hamida N., Ben Abdallah-Ben Hadj Hamida O., Jarboui O., Missaoui H. 2015. Diet composition and feeding habits of Lithognathus mormyrus (Sparidae) from the Gulf of Gabes (Central Mediterranean). Journal of the Marine Biological Association of the United Kingdom 96 (7): 1-8. DOI: 10.1017/S0025315415001769

Besseau L., Faliex E. 1990. Présence de granulocytes et de "corps bruns" dans l'ovotestis de marbré Lithognathus mormyrus (L., 1758) (Téléostéen, Sparidae). Ichtyophysiologica Acta 13: 109-114.

Bradaï M.N., Jarboui O., Ghorbel M., Bouaïn A., El Abed A. 1998. Régime alimentaire de Diplodus annularis et de Lithognathus mormyrus (Teleostei, Sparidae) dans la région du golfe de Gabès. Bulletin de l'Institut National des Sciences et Technologies de la Mer 4: 12-15.

Campillo A. 1992. Les pêcheries françaises de Méditerranée. Synthèse des connaissances. Contrat CEE/IFREMER n* 92/1211 625/TF. Institut Français de Recherche pour l'Exploitation de la Mer, Sète.

Chessa L.A., Lanera P., Pais A., Plastina N., Scardi M., Serra S., Valiente M.L., Vinci D. 2005. Aspetti del regime alimentare di Lithognathus mormyrus (Linnaeus, 1758) nello stagno di Calich (Sardegna nord occidentale). [Aspects of the diet of Lithognathus mormyrus (Linnaeus, 1758) in the Calich pond (northwestern Sardinia).] Biologia Marina Mediterranea 12 (1): 492-495. [In Italian.]

Dorel D. 1986. Poissons de l'Atlantique nord-est: relations taille-poids. Institut Francais de Recherche pour l'Exploitation de la Mer. Nantes, France.

Emre Y., Balık İ., Sümer Ç., Oskay D.A., Yeşilçimen Ö. 2010. Age, growth, length-weight relationship and reproduction of the striped sea bream (Lithognathus mormorus L., 1758) (Sparidae) in the Beymelek lagoon (Antalya, Turkey). Turkish Journal of Zoology 34 (1): 93-100. DOI: 10.3906/zoo-0808-13

Erkoyuncu İ. 1995. Balıkçılık biyolojisi ve populasyon dinamigi. [Biology of fisheries and population dynamics.] Ondokuz Mayıs Üniversitesi, Su Ürünleri Fakültesi, Sinop, Turkey. [In Turkish.]

Fischer W., Schneider M., Bauchot M.-L. 1987. Fiches FAO d'identification des espèces pour les besoins de la pêche (Révision 1). Méditerranée et mer Noire. Zone de pêche 37. Vol. 2. Vertébrés. FAO, Rome. 
Froese R. 2006. Cube law, condition factor and weightlength relationships: History, meta-analysis and recommendations. Journal of Applied Ichthyology 22 (4): 241-253. DOI: 10.1111/j.1439-0426.2006.00805.x

Gökçe G., Aydın İ., Metin C. 2007. Length-weight relationships of 7 fish species from the north Aegean Sea. International Journal of Natural and Engineering Sciences 1 (1): 51-52.

Gonçalves J.M.S., Bentes L., Lino P.G., Ribeiro J., Canário A.V.M., Erzini K. 1997. Weight-length relationships for selected fish species of the smallscale demersal fisheries of the south and south-west coast of Portugal. Fisheries Research 30 (3): 253-256. DOI: 10.1016/S0165-7836(96)00569-3

Harchouche K., Maurin C., Quéro J.C. 2005. Inventaire des proies ingérées par le marbré Lithognathus mormyrus (Linnaeus, 1758) (Pisces: Perciformes: Sparidae) dans la baie d'Alger et d'Annaba. Annales de la Société des Sciences Naturelles de la CharenteMaritime 9 (5): 491-502.

Hossain M.Y., Sayed S.R.M., Mosaddequr Rahman M., Ali M.M., Hossen M.A., Elgorban A.M., Ahmed Z.F., Ohtomi J. 2015. Length-weight relationships of nine fish species from the Tetulia River, southern Bangladesh. Journal of Applied Ichthyology 31 (5): 967-969. DOI: 10.1111/jai.12823

Houston A.I., McNamara J.M. 1999. Models of adaptive behaviour: An approach based on state. Cambridge University Press, Cambridge, UK.

Jardas I. 1996. Jadranska ihtiofauna. [Adriatic ichthyofauna.]. Školska knjiga, Zabreb, Croatia. [In Croatian.]

Kallianiotis A., Torre M., Argyri A. 2005. Age, growth, mortality, reproduction, and feeding habits of the striped seabream, Lithognathus mormyrus (Pisces: Sparidae), in the coastal waters of the Thracian Sea, Greece. Scientia Marina 69 (3): 391-404. DOI: 10.3989/scimar.2005.69n3391

Keskin C., Gaygusuz Ö. 2010. Length-weight relationships of fishes in shallow waters of Erdek Bay (Sea of Marmara, Turkey). Istanbul University Faculty of Science Journal of Biology 69 (1): 25-32.

Kimura D.K. 1980. Likelihood methods for the von Bertalanffy growth curve. Fishery Bulletin 77 (4): 765-776.

Kjerfve B. 1994. [Chapter 1] Coastal lagoons. Pp. 1-8. In: Kjerfve B. (ed.) Coastal lagoon processes. Elsevier Oceanography Series Vol. 60. Elsevier Science Publishers, Amsterdam, the Netherlands.

Koutrakis E.T., Tsikliras A.C. 2003. Length-weight relationships of fishes from three northern Aegean estuarine systems (Greece). Journal of Applied Ichthyology 19 (4): 258-260. DOI: 10.1046/j.14390426.2003.00456.x

Kraljević M., Dulčić J., Cetinić P., Pallaoro A. 1996. Age, growth and mortality of the striped sea bream, Lithognathus mormyrus L., in the northern Adriatic. Fisheries Research 28 (4): 361-370. DOI: 10.1016/ S0165-7836(96)00518-8
Kraljević M., Dulčić J., Pallaoro A., Cetinić P., JugDujaković J. 1995. Sexual maturation, age and growth of striped sea bream, Lithognathus mormyrus L., on the eastern coast of the Adriatic Sea. Journal of Applied Ichthyology 11 (1-2): 1-8. DOI: 10.1111/ j.1439-0426.1995.tb00001.x

Labourg P.J., Clus C., Lasserre G. 1985. Résultats préliminaires sur la distribution des juvéniles de poissons dans un marais maritime du Bassin d'Arcachon. Oceanologica Acta 8 (3): 331-341.

Li Q., Xu R., Huang J. 2013. Length-weight relations for 20 fish species from the Pearl River, China. Acta Ichthyologica et Piscatoria 43 (1): 65-69. DOI: 10.3750/AIP2013.43.1.09

Lorenzo J.M., Pajuelo J.G., Mendez-Villamil M., Coca J., Ramos A.G. 2002. Age, growth, reproduction and mortality of the striped seabream, Lithognathus mormyrus (Pisces, Sparidae), off the Canary Islands (central-eastAtlantic). Journal of Applied Ichthyology 18 (3): 204-209. DOI: 10.1046/j.1439-0426.2002.00318.x

Mariani S. 2006. Life-history and ecosystem-driven variation in composition and residence pattern of seabream species (Perciformes: Sparidae) in two Mediterranean coastal lagoons. Marine Pollution Bulletin 53 (1-4): 121-127. DOI: 10.1016/j. marpolbul.2005.09.019

Mille T., Mahe K., Villanueva M.C., De Pontual H., Ernande B. 2015. Sagittal otolith morphogenesis asymmetry in marine fishes. Journal of Fish Biology 87 (3): 646-663. DOI: 10.1111/jfb.12746

Monteiro P., Bentes L., Coelho R., Correia C., Erzini K., Lino P.G., Ribeiro J., Gonçalves J.M.S. 2010. Age and growth, mortality and reproduction of the striped sea bream Lithognathus mormyrus Linnaeus, 1758, from the South Coast of Portugal (Algarve). Marine Biology Research 6 (1): 53-65. DOI: 10.1080/17451000903039731

Morales-Nin B.Y.O. 1987. The influence of environmental factors on microstructure of otoliths of three demersal fish species caught off Namibia. South African Journal of Marine Science 5 (1): 255-262. DOI: $10.2989 / 025776187784522207$

Morales-Nin B., Ralston S. 1990. Age and growth of Lutjanus kasmira (Forskål) in Hawaiian waters. Journal of Fish Biology 36 (2): 191-203. DOI: 10.1111/j.1095-8649.1990.tb05595.x

Morey G., Moranta J., Massutí E., Grau A., Linde M., Riera F., Morales-Nin B. 2003. Weight-length relationships of littoral to lower slope fishes from the western Mediterranean. Fisheries Research 62 (1): 8996. DOI: 10.1016/S0165-7836(02)00250-3

Munro J.L., Pauly D. 1983. A simple method for comparing growth of fishes and invertebrates. ICLARM Fishbyte 1: 5-6

Nelson J.S. 2006. Fishes of the World. 4th edn. John Wiley and Sons, Hoboken NJ, USA.

Newell R.C. 1982. The energetics of detritus utilisation in coastal lagoons and nearshore waters. Oceanologica Acta 1 (Special issue): 377-355. 
Osman M. 2005. Age and growth of Lithognathus mormyrus (Teleostei, Sparidae) in Mediterranean waters off Alexandria, Egypt. Egyptian Journal of Aquatic Research 31 (2): 274-280.

Pajuelo J.G., Lorenzo J.M., Méndez M., Coca J., Ramos A.G. 2002. Determination of age and growth of the striped seabream Lithognathus mormyrus (Sparidae) in the Canarian archipelago by otolith readings and backcalculation. Scientia Marina 66 (1): 27-32. DOI: 10.3989/scimar.2002.66n127

Panfili J., de Pontual H., Troadec H., Wright P.J. (eds.) 2002. Manuel de sclérochronologie des poissons. IRD et Ifremer, Paris, France.

Papaconstantinou C., Mytilineou C., Panos T. 1988. Aspects of the life history and fishery of red pandora, Pagellus erythrinus (Sparidae) off western Greece. Cybium 12 (4): 267-280.

Ricker W.E. 1973. Linear regression in fishery research. Journal of the Fisheries Research Board of Canada 30 (3): 409-434. DOI: 10.1139/f73-072

Russel B., Carpenter K.E., Pollard D., Mann B.Q., Buxton C.D. 2014. Lithognathus mormyrus. The IUCN Red List of Threatened Species 2014: e.T170160A1284573. IUCN. [Downloaded on on 3 November 2016.] DOI: 10.2305/IUCN.UK.2014-3. RLTS.T170160A1284573.en

Saleh M., Soegianto A. 2017. Length-weight relations of pelagic fish species from eastern region of Java Sea, Indonesia. Acta Ichthyologica et Piscatoria 47 (3): 307-309. DOI: 10.3750/AIEP/02168

Santos M.N., Gaspar M.B., Vasconcelos P., Monteiro C.C. 2002. Weight-length relationships for 50 selected fish species of the Algarve coast (southern Portugal). Fisheries Research 59 (1-2): 289-295. DOI: 10.1016/ S0165-7836(01)00401-5

Spiegel M.R., Ergas A., Marcotorchino J.-F. 1991. Théorie et applications de la statistique. McGraw-Hill, Paris, France.

Suau P. 1969. Contribución al estudio de la biología de la herrera, «Lithognathus (=Pagellus) mormyrus L. » (Peces espáridos). Publicaciones técnicas de la Junta de Estudios de Pesca 8: 163-174.

Sümer Ç. 2012. Length-weight relationships of 15 lagoon fish species collected in the Beymelek Lagoon (SW Turkey). Cahiers de Biologie Marine 53 (2): 185-188. DOI: 10.21411/CBM.A.BF51DD1C

Sümer C., Ozdemir G., Ertekin H. 2014. Age, growth and reproduction of the striped seabream, Lithognathus mormyrus (Pisces: Sparidae), in the Beymelek Lagoon (southwestern coast of Turkey). Cahiers de Biologie Marine 55 (1): 37-42. DOI: 10.21411/ CBM.A.D2639BEA
Tobes I., Miranda R., Pino-del-Carpio A., AraujoFlores J.M., Ortega H. 2016. Length-weight relationships of freshwater fishes of the Alto Madre de Dios River (Manu Biosphere Reserve, Peru). Journal of Applied Ichthyology 32 (6): 1256-1258. DOI: 10.1111/jai.13172

Trojette M., Ben Faleh A., Fatnassi M., Marsaoui B., Mahouachi N.E.H., Chalh A., Quignard J.-P., Trabelsi M. 2015. Stock discrimination of two insular populations of Diplodus annularis (Actinopterygii: Perciformes: Sparidae) along the coast of Tunisia by analysis of otolith shape. Acta Ichthyologica et Piscatoria 45 (4): 363-372. DOI: 10.3750/ AIP2015.45.4.04

Turan C. 1999. Anote on the examination of morphometric differentiation among fish populations: The truss system. Turkish Journal of Zoology 23 (3): 259-263.

Türkmen M., Akyurt İ. 2003. Growth characteristics, sex inversion and mortality rates of striped sea bream, Lithognathus mormyrus L., in İskenderun Bay. Turkish Journal of Zoology 27 (4): 323-329.

Vieira A.R., Farias I., Figueiredo I., Neves A., MoralesNin B., Sequeira V., Martins M.R., Gordo L.S. 2009. Age and growth of black scabbardfish (Aphanopus carbo Lowe, 1839) in the southern NE Atlantic. Scientia Marina 73 (S2): 33-46. DOI: 10.3989/ scimar.2009.73s 2033

Vitale S., Arkhipkin A., Cannizzaro L., Scalisi M. 2011. Life history traits of the striped seabream Lithognathus mormyrus (Pisces, Sparidae) from two coastal fishing grounds in the Strait of Sicily. Journal of Applied Ichthyology 27 (4): 1086-1094. DOI: 10.1111/j.14390426.2011.01775.x

Vitale S., Cannizzaro L., Bono G., Beltrano A.M., Milazzo A., Cusumano S. 2003. Maturità sessuale, età e accrescimento della mormora, Lithognathus mormyrus (L., 1758) (Pisces; Sparidae) costa sud occidentale della Sicilia. [Sexual maturity, age and accretion of the mormora, Lithognathus mormyrus (L., 1758) (Pisces; Sparidae), south-west coast of Sicily.] Biologia Marina Mediterranea 10 (2): 233-241. [In Italian.]

von Bertalanffy L. 1938. A quantitative theory of organic growth (inquiries on growth laws. II). Human Biology 10 (2): 181-213.

Received: 31 May 2018

Accepted: 27 August 2018

Published electronically: 31 December 2018 